\title{
sciendo
}

\section{THE COST OF CAPITAL FOR INVESTMENT IN THE WARSAW STOCK EXCHANGE INDEXES - VERSUS DJIA*}

\author{
Stanisław Urbański, Ph.D., Associate Professor \\ University of Science and Technology \\ Faculty of Management \\ e-mail:surbansk@zarz.agh.edu.pl \\ ORCID: 0000-0002-8020-8471
}

Received 28 October 2020, Accepted 12 April 2021

\begin{abstract}
Research background and purpose: The CAPM, Fama-French and modified Fama-French models were used to estimate the cost of the capital of the DJIA and selected Polish stock indexes were used. The estimated cost of capital was the cost of the portfolio of corporate investment projects estimated by market returns.

Research methodology: The model tests were run on 276 monthly returns of stocks listed on the markets in the years 1995-2019. The bootstrap method to estimate the confidence interval of the cost of capital was used.

Results: The highest and positive cost of capital median was found for the DJIA index, about $0.85 \%$ monthly, and for the WIG20 and WIGDIV indexes, about $0.25 \%$ monthly. The cost of capital median for the mWIG80, WIGBANK and WIGCHEMIA indexes were found to be negative. This was due to large errors in the estimated cost of capital.

Novelty: Minor errors in the estimation of the cost of capital of index DJIA may result from a more rational policy for the implementation of investment projects by companies included in the index.
\end{abstract}

Keywords: ICAPM, Cost of capital, Risk premium, Bootstrap method

JEL classification: G11, G12

\footnotetext{
* This work is supported by the National Science Centre, Poland (Research Grant 2015/19/B/HS4/01294).
} 


\section{Introduction}

The aim of the present study was to estimate the cost of capital of chosen stock indexes using the CAPM, the classic Fama and French (1993) model, and the modified Fama and French model proposed by Urbański (2012) - which are hereafter denoted as FF and MFF. The cost of capital was estimated for the following indexes: DJIA, WIG20, WIG30, WIGDIV, mWIG80, WIGBANK and WIGCHEMIA.

In connection with the aim of the study, a conjecture was put forward that the use of three different pricing applications would allow for a precise and similar estimation of the cost of capital of the analysed indexes.

This work is a continuation of the work presented at the IBIMA35 Conference by Urbański, Zarzecki and Leskow (2020) in which the authors attempted to estimate the cost of the capital of entire selected market portfolios.

The literature review is presented in Section 1. The procedures for estimating the cost of capital by the CAPM and two ICAPM applications (FF and MFF models) is explained in Section 2. The risk premium is estimated on the basis of the classic and two passes procedures. Also, a bootstrap method (with 5000 iterations) was used to create a confidence interval of the estimated cost of capital. ${ }^{1}$ The data and methods of the portfolios construction are provided in Section 3. Section 4 shows and analyses the estimated cost of the capital and its bootstrapped confidence intervals for the tested indexes. In this Section the impact of different penny thresholds on the estimated cost of capital is analysed. In addition, statistic test results comparing the values of cost of capital for different boundary conditions for the analysed indexes are presented. The discussion concerning the confidence interval of the estimated cost of capital is presented in Section 5. The final section offers the conclusions.

\section{The empirical literature}

The correct interpretation of the cost of capital is of fundamental methodological importance and determines the proposed estimation procedures. There are basically two general concepts for determining the cost of capital. One based on book value - designed by the discounted cash flow (DCF) approach, another based on market value - designed by single-factor or multifactor approaches such as the classic CAPM or ICAPM proposed by Merton (1973); however this is limited to public companies.

\footnotetext{
1 Bootstrap methods are widely described by Efron and Tibshirani (1993).
} 
For non-public companies, the procedure proposed by Hamada (1972) may be applied. The DCF method does not allow the cost of capital to depend on the value of risk taken. In other words, what part of the cost of capital relates to the risk-free investment and what part for the risk taken? Therefore, according to the statement of Pratt (2002) unquestionably more information concepts seem to be based on market values. In his work, Pratt (2002, p. 185) states: "The cost of capital is market driven and that is a function of the investment, not the investor. ... Cost of capital is the expected rate of return that the market requires to induce investment in a subject security." This interpretation clearly indicates the application of marketbased methods. An investor is a person (generally a company) undertaking a business activity, implementing a given investment. In turn, business activity is mostly related to realized and planned risk-bearing investments. The expected return on risky investments can only be estimated based on the market values of the subject of the investment. The return estimated in this way is the cost of capital related to the given investment project. The company can simultaneously carry out many investment projects related to each other. Individual projects can also be mutually hedged by including the real options on realized investment portfolio. Individual projects can generate negative returns but if and only if their implementation is necessary to realize the entire investment portfolio. Therefore, it can be concluded that the cost of capital of the investment generating negative returns is negative. However, it is unacceptable that the expected return on an independent investment project could be negative. Such an investment project should be rejected by the company. The presented consideration inclines to the conclusion that the expected return on business activity of the company should be positive. Thus, the cost of capital of a company conducting a rational economic policy should be positive.

However, as mentioned above, the return on investment is estimated by market values. The return on a business can be estimated only on the basis of the market value of the company, mainly stock market prices, as perceived by an external investor. The external investor, on the other hand, does not know the company's policy regarding relations between individual projects and the real options related to these projects. This causes that stock market prices are influenced by the internal hedging conditions implemented by the company. The behavioural proceedings of a selected group of investors also has an unexplored impact on market stock prices. Therefore, the risk premium and the company's systematic risk cannot constitute a linear function of the firm's project betas. This, in turn, means that so calculated returns may be inconsistent in light of the CAPM or ICAPM. This phenomenon is explained as price anomalies described, among others, in the works of Rosenberg, Reid and Lanstein (1985), Bhandari (1988), Jegadeesh and Titman (1993), Lakonishok, Shleifer and Vishny (1994), and Fama and French (1992). 
Well-known literature studies attempt to explain a company's pricing based on stock market prices, is partially inconsistent with the CAPM (see Jagannathan, Wang, 1996; Berk, Green, Naik, 1999; Bernardo, Chowdry, Goyal, 2007; Zhi, Guo, Jagannathan, 2012). The results of the work indicate that the cost of capital of investment projects, estimated by the CAPM, can be appropriate even when the pricing of a company is not consistent with CAPM. Zhi et al. (2012, p. 205) conclude "... the CAPM could work well on the option-adjusted risk premium and beta", and propose the procedures to estimate option-adjusted stock returns, option-adjusted betas and the option-adjusted risk premium, which are free from the impact of real options. In other words the CAPM without a real-option adjustment rightly estimates the cost of capital of individual projects, although the pricing of the entire company is not in line with the CAPM. Therefore, it can be concluded that the cost of capital estimated without real-option adjustment cannot constitute a benchmark for assessing the company's new investment projects. While, the cost of capital assessed by market returns, and without a real-option adjustment can be useful for managing the portfolios of listed securities.

The considerations in the above paragraph lead to the conclusion that the cost of capital estimated on the basis of market returns may be loaded with large errors. The assumptions of the need for a correct estimate of the cost of capital of an entire company, using the ICAPM are as follows:

- rational policy for the implementation of investment projects,

- no impact of behavioural stock pricing by investors,

- no non-linear relationships between returns with ongoing investment projects,

- no open real options regarding ongoing investment projects,

- correct procedures for the estimating of option-adjusted returns, option-adjusted betas and the option-adjusted risk premium - if real options are opened by a company.

Failure to meet the above conditions may generate large methodological and estimation errors. Failure to comply with these conditions may or may not result in a negative median value of the estimated cost of capital.

The paper of Kozarević and Džafić (2014) is an example of a work on the use of the CAPM to estimate the cost of capital on the Sarajevo Stock Exchange. Other examples may be the work of Barnes and Lopez (2006) and King (2009) for estimating the cost of capital of banks in chosen countries. The applied procedures for evaluating the cost of capital use the financial form of the CAPM. However, this procedure gives no answer whether the used pricing application of the CAPM generates mean-variance-efficient portfolios of the tested market 
(see Urbański, 2019). ${ }^{2}$ In the light of Ferson and Locke (1998), the exact determination of the confidence interval of the cost of capital is in this case complex and even impossible. The reason for this is the unknown distribution of the cost of capital, which is a non-linear function of risk premium and systematic risk. The use of bootstrap methods overcomes this problem and allows estimating the confidence interval.

\section{Analytical approaches}

The ICAPM financial form can be stored by equation (1):

$$
E\left(r_{i}\right)=E(R F)+\sum_{k=1}^{K} \beta_{i k} E\left(F_{k}\right)
$$

where $\beta_{i k}$ is the systematic risk vector of asset $i, E\left(F_{k}\right)$ is the expected value of risk premium vector defined as the expected value of factors $F_{k}$ for the analysed market, $E(R F)$ is an expected return on a risk free asset, and $E\left(r_{i}\right)$ is the expected return on an analyzed asset.

If the classic CAPM is analysed, $E\left(r_{i}\right)$ depends only on an excess on market return $R M$ over risk free asset. If the classic FF model is analysed, $E\left(r_{i}\right)$ depends on three well known factors: $R M-R F, H M L$ and $S M B$. If the MFF model is analysed, $E\left(r_{i}\right)$ depends on factors: $R M$ $R F, H M L N$ and $L M H D$, defined by Urbanski (2012).

Correct determination of the cost of capital of the audited asset requires an estimation of expected values $E(R F)$ and $E\left(F_{k}\right)$ as well as all components of systematic risk $\beta_{i k}$. Therefore, the cost of capital $\mathrm{Ccap}_{i}$ (of the audited asset $i$ ) is estimated by equation (2):

$$
\operatorname{Ccap}_{i}=\widehat{E(R F)}+\sum_{k=1}^{K} \widehat{\beta_{i k}^{T}} \widehat{E\left(F_{k}\right)}
$$

Systematic risk components $\widehat{\beta_{i k}^{T}}$ are estimated using $T$ periods. Expected values $E(R F)$ and $E\left(F_{k}\right)$ can be estimated based on two procedures.

\subsection{Classic procedure}

Estimators $E(R F)$ and $E\left(F_{k}\right)$ can be expressed by equations (3) and (4):

$$
\widehat{E(R F)}=1 / T \sum_{t=1}^{T} R F_{t}
$$

\footnotetext{
2 The pricing application of assets is consistent with the CAPM if it generates mean-variance-efficient portfolios, see Fama (1996).
} 


$$
\widehat{E\left(F_{k}\right)}=1 / T \sum_{t=1}^{T} F_{k t}
$$

if the CAPM is tested:

$$
\widehat{E\left(F_{1}\right)}=\widehat{E(R M-R F)}=1 / T \sum_{t=1}^{T}\left(R M_{t}-R F_{t}\right)
$$

if the FF model is tested:

$$
\begin{gathered}
\widehat{E\left(F_{1}\right)}=\widehat{E(R M-R F)}=1 / T \sum_{t=1}^{T}\left(R M_{t}-R F_{t}\right) \\
\widehat{E\left(F_{2}\right)}=\widehat{E(H M L)}=1 / T \sum_{t=1}^{T} H M L_{t} \\
\widehat{E\left(F_{3}\right)}=\widehat{E(S M B)}=1 / T \sum_{t=1}^{T} S M B_{t}
\end{gathered}
$$

if the MFF model is tested ${ }^{3}$ :

$$
\begin{gathered}
\widehat{E\left(F_{1}\right)}=\widehat{E(R M-R F)}=1 / T \sum_{t=1}^{T}\left(R M_{t}-R F_{t}\right) \\
\widehat{E\left(F_{2}\right)}=\widehat{E(H M L N)}=1 / T \sum_{t=1}^{T} H M L N_{t} \\
\widehat{E\left(F_{3}\right)}=\widehat{E(L M H D)}=1 / T \sum_{t=1}^{T} L M H D_{t} .
\end{gathered}
$$

\subsection{II pass procedure}

The two-pass econometric model in order to estimate the expected values $E(R F)$ and $E\left(F_{k}\right)$ is constructed.

In the first pass:

$$
r_{i t}-R F_{t}=\beta_{i 0}+\sum_{k=1}^{K} \beta_{i k} F_{k t}+e_{i t} ; t=1, \ldots, T ; “ i=1, \ldots, m
$$

where $F_{k t}$ is the value of the $k$ factor model in period $t$.

In the second pass:

$$
r_{i t}=\gamma_{0}+\sum_{k=1}^{K} \gamma_{k} \widehat{\beta_{i k}}+e_{i t} ; t=1, \ldots, T ; i=1, \ldots, m
$$

\footnotetext{
3 The MFF model is proposed by Urbanski (2012) and modified by Urbanski and Leskow (2020). The MFF model and $H M L N$ and $L M H D$ factors are shortly described in the Appendix.
} 
The estimated value of $\gamma_{0}$ is the estimator of $E(R F)$ :

$$
\widehat{E(R F)}=\widehat{\gamma_{0}}
$$

Similarly, in the case of the FF model:

$$
\begin{aligned}
& \widehat{E\left(F_{2}\right)}=E \widehat{(H M L)}=\gamma_{H M L} \\
& \left.\widehat{E\left(F_{3}\right)}=E \widehat{(S M B}\right)=\gamma_{S M B}
\end{aligned}
$$

and in the case of the MFF model:

$$
\begin{aligned}
& \widehat{E\left(F_{2}\right)}=\widehat{E(H M L N)}=\gamma_{H M L N} \\
& \widehat{E\left(F_{3}\right)}=E \widehat{E(L M H D)}=\gamma_{L M H D}
\end{aligned}
$$

$\widehat{\beta_{i k}^{T}}$ in equation (2) is estimated using the regression (13):

$$
r_{i t}=\beta_{i 0}^{T}+\sum_{k=1}^{K} \beta_{i k}^{T} F_{k t}+s_{i t} ; t=1, \ldots, T ; “ i=1, \ldots, m
$$

The error of cost of capital estimation is assessed using the bootstrap method by bootstrapping the residuals of models (3 and 4), (5), (6a, 6b and 6c), (7a, 7b and 7c), (8), (9) and (13).

\section{Data}

The cost of the capital of the chosen indexes using the CAPM and the FF and MFF models is evaluated. The paper analyzes 276 monthly returns of the stocks listed on the main market of the Warsaw Stock Exchange (WSE) and on the US market in 1995-2019 (characterized by their positive book value). It estimates the cost of capital for 8 stock indexes:

1. Seven indexes of the WSE: WIG20, WIG30, WIGDIV, mWIG80, WIGBANK and WIGCHEMIA. The cost of capital is estimated by the CAPM, the FF and the MFF models. In order to examine the impact of penny stocks on the simulation results, the cost of the capital of these indexes is estimated by eliminating penny stocks, with market values lower than 0.5, 1.0, 2.0, 3.0, 4.0 and 5.0 PLN.

2. The Dow Jones Industrial Average index. The cost of capital is estimated by the CAPM and the FF model. To estimate the cost of capital for the DJIA, data from the Kenneth 
R. French - Data Library is used. ${ }^{4}$ This database does not include the financial results of companies that the MFF model requires. That is why the cost of capital for the DJIA is estimated only by the FF and CAPM.

In the case of the CAPM and the FF model the portfolios are formed in two directions on book value to market value $(B / M)$ and capitalization (Size) at the end of the months of the previous quarter. In the case of the CAPM and the MFF model the portfolios are formed in two directions on NUM and DEN. $.^{5} / M$ and Size, and NUM and DEN for portfolios are the arithmetic means of these functions of various portfolio securities. Returns on given portfolios are average stock returns weighted by market capitalizations.

In the case of estimation of the cost of capital for the WSE indexes, the values of model factors $\widehat{E\left(F_{k}\right)}$ are calculated using the data provided by the WSE (stock prices, book value and Size of stocks) and the database established by the Notoria Serwis Company (for NUM and DEN calculations).

In the case of the estimation of the cost of capital for the DJIA the values of model factors $\widehat{E\left(F_{k}\right)}$ are calculated using time series provided by the Kenneth R. French-Data Library.

The monthly value weighted portfolio returns, as well as the factor values are calculated on the basis of prices in the PLN currency (for the cost of capital for the WSE indexes estimation) and in US dollars (for the DJIA), and include dividends, the value of the right to buy new stocks for existing shareholders, and capital gains. Market return $R M-R F$ is the return on the market index: minus the Polish one month T-bill rate (for the cost of capital for the WSE indexes estimation), and minus the US one month T-bill rate (for the DJIA).

The expected value of risk premium vector $E\left(F_{k}\right)$ and the expected return of risk free asset $E(R F)$ are estimated from the entire historical period.

If estimation for the classic procedure is applied $\widehat{E(R F)} 1 / 276 \sum^{276} R F$ and $\widehat{E\left(F_{k}\right)}=1 / 276 \sum_{t=1}^{276} F_{k t}$. If estimation for the II pass procedure is applied, systematic risk $\beta_{i k}$ and risk premium components $\gamma_{k}$ are estimated on the basis of the two-pass econometric model using 276 months. The regression parameters are estimated using the GLS method according to the Prais-Winsten procedure where first-order autocorrelation of the residual components is taken into account. The heteroscedascity of residuals is justified by the transformation of variables. The errors-in-variables are corrected by Shanken's (1992) statistic.

The cost of capital values are assessed using the self-designed computer code in Fortran.

\footnotetext{
${ }_{4}$ See http://mba.tuck.dartmouth.edu/pages/faculty/ken.french/data_library.html.

5 The procedures of the $N U M$ and $D E N$ calculation are shown in the Appendix.
} 
The assessed cost of capital value depends on the period for estimating the beta components. Regression (13) is used to estimate betas from 48 and 60 last months.

\section{Results and their analysis}

Tables 1 and 2 show the strapped medians and confidence intervals of the cost of capital for investment in the chosen stock indexes estimated by the FF and MFF models.

Table 1. Percentage values of the cost of capital (Ccap) for investment in chosen stock indexes estimated by the classic Fama-French model

\begin{tabular}{|c|c|c|c|c|c|c|}
\hline \multirow{3}{*}{$\begin{array}{c}\begin{array}{c}\text { Est. } \\
\text { method/ }\end{array} \\
\widehat{\beta_{i M}^{T}} \\
\text { periods } T, \\
\text { months }\end{array}$} & \multicolumn{6}{|c|}{$\begin{array}{c}\text { Cost of capital, } \% \text { monthly } \\
(95 \% \text { confidence interval) } \\
\text { (width of } 95 \% \text { confidence interval) }\end{array}$} \\
\hline & $\begin{array}{l}\operatorname{Ccap}_{i}= \\
+\widehat{E(H}\end{array}$ & $\widehat{\beta_{i, H M L}}+\widehat{E(S}$ & $\begin{array}{l}\text { F) } \beta_{i M}^{T}+ \\
\widehat{\beta_{i, S M B}}\end{array}$ & $\operatorname{Ccap}_{i}=\widehat{\gamma_{0}}+\widehat{\gamma}$ & I pass procedur & $\widehat{\gamma_{S M B}} \widehat{\beta_{i, S M B}}$ \\
\hline & DJIA & WIG20 & WIGDIV & mWIG80 & WIGBANK & WIGCHEMIA \\
\hline Classic/48 & $\begin{array}{c}0.82 \\
(0.29 \div 1.34) \\
(1.05)\end{array}$ & $\begin{array}{c}-0.27 \\
(-1.21 \div 0.60) \\
(1.81)\end{array}$ & $\begin{array}{c}-0.15 \\
(-0.99 \div 0.63) \\
1.62\end{array}$ & $\begin{array}{c}-0.02 \\
(-0.68 \div 0.54) \\
(1.23)\end{array}$ & $\begin{array}{c}-0.12 \\
(-2.64 \div 2.78) \\
(5.42)\end{array}$ & $\begin{array}{c}-0.02 \\
(-1.13 \div 0.86) \\
(1.99)\end{array}$ \\
\hline Classic/60 & $\begin{array}{c}0.81 \\
(0.29 \div 1.33) \\
(1.04)\end{array}$ & $\begin{array}{c}-0.24 \\
(-1.15 \div 0.68) \\
(1.82)\end{array}$ & $\begin{array}{c}-0.15 \\
(-0.95 \div 0.66) \\
(1.61)\end{array}$ & $\begin{array}{c}-0.15 \\
(-0.77 \div 0.50) \\
(1.26)\end{array}$ & $\begin{array}{c}-0.16 \\
(-2.29 \div 1.85) \\
(4.15)\end{array}$ & $\begin{array}{c}0.06 \\
(-0.85 \div 0.90) \\
(1.75)\end{array}$ \\
\hline II pass/48 & $\begin{array}{c}0.85 \\
(0.75 \div 0.94) \\
(0.20)\end{array}$ & $\begin{array}{c}0.28 \\
(-0.21 \div 0.87) \\
(1.08)\end{array}$ & $\begin{array}{c}-0.03 \\
(-0.35 \div 0.41) \\
(0.76)\end{array}$ & $\begin{array}{c}-0.81 \\
(-1.68 \div-0.22) \\
(1.46)\end{array}$ & $\begin{array}{c}-0.78 \\
(-4.99 \div 3.32) \\
(8.31)\end{array}$ & $\begin{array}{c}-0.42 \\
(-1.81 \div 0.70) \\
(2.51)\end{array}$ \\
\hline II pass/60 & $\begin{array}{c}0.87 \\
(0.77 \div 0.95) \\
(0.18)\end{array}$ & $\begin{array}{c}0.27 \\
(-0.19 \div 0.87) \\
1.06\end{array}$ & $\begin{array}{c}-0.01 \\
(-0.32 \div 0.40) \\
(0.72)\end{array}$ & $\begin{array}{c}-0.79 \\
(-1.54 \div-0.29) \\
(1.25)\end{array}$ & $\begin{array}{c}-0.80 \\
(-4.21 \div 2.57) \\
(6.78)\end{array}$ & $\begin{array}{c}-0.42 \\
(-1.72 \div 0.60) \\
(2.32)\end{array}$ \\
\hline
\end{tabular}

Notes: this table presents the bootstrapped median and confidence intervals of the Ccap for the tested indexes estimated by the classic Fama-French model. The risk premium is estimated using $B / M$ and Size portfolios. The $95 \%$ confidence intervals and the widths of the corresponding confidence intervals appear in brackets; 1995-2019, 276 months.

Source: own research.

The cost of the capital median of the WIG20, estimated by the II pass of the FF and MFF models, assumes positive and similar values of around $0.25 \%$ per month. The widths of confidence intervals are also similar and amount to about $1 \%$. A positive value of cost of capital median (of about $0.25 \%$ per month) is also found in the case of the WIGDIV index, but only for estimations using the MFF model. The cost of capital medians of the other indexes tested using the II pass FF and MFF models are negative. The lowest and negative median of the cost of capital is found for the WIGBANK index, and for the last 48 months of estimation it is 
about $-0.96 \%$ per month if the MFF model is used and about $-0.78 \%$ per month if the FF model is used. Also, the widths of the WIGBANK index confidence intervals are the largest. High negative values of the cost of capital median are also found for index mWIG80, about $-0.81 \%$ if the FF model is used and about $-0.26 \%$ if the MFF model is used.

If the cost of capital is estimated using the classic procedure, then the median values of all indexes are negative.

Table 2. Percentage values of the cost of capital (Ccap) for investment in chosen stock indexes estimated by the modified Fama-French model

\begin{tabular}{|c|c|c|c|c|c|}
\hline \multirow{3}{*}{$\begin{array}{l}\text { Est. } \\
\text { method/ } \\
\widehat{\beta_{i M}^{T}} \\
\text { periods } T, \\
\text { months }\end{array}$} & \multicolumn{5}{|c|}{$\begin{array}{l}\text { Cost of capital, } \% \text { monthly } \\
\text { ( } 95 \% \text { confidence interval) } \\
\text { (width of } 95 \% \text { confidence interval) }\end{array}$} \\
\hline & \multicolumn{2}{|c|}{$\begin{array}{c}\text { Classic procedure } \\
\operatorname{Ccap}_{i}=\widehat{E(R F)}+\widehat{E(R M-R F) \widehat{\beta_{i M}^{T}}+} \\
+\widehat{E(H M L N)} \widehat{\beta_{i, H M L N}}+\widehat{E(L M H D)} \widehat{\beta_{i, L M H D}}\end{array}$} & \multicolumn{3}{|c|}{$\operatorname{Ccap}_{i}=\widehat{\gamma_{0}}+\widehat{\gamma_{M}} \widehat{\beta_{i M}^{T}}+\widehat{\gamma_{H M L N}} \widehat{\beta_{i, H M L N}}+\widehat{\gamma_{L M H D}} \widehat{\beta_{i, L M H D}}$} \\
\hline & WIG20 & WIGDIV & mWIG80 & WIGBANK & WIGCHEMIA \\
\hline Classic/48 & $\begin{array}{c}-0.12 \\
(-1.07 \div 0.76) \\
(1.83)\end{array}$ & $\begin{array}{c}-0.06 \\
(-0.89 \div 0.72) \\
(1.60)\end{array}$ & $\begin{array}{c}-0.54 \\
(-1.23 \div 0.08) \\
(1.31)\end{array}$ & $\begin{array}{c}-1.87 \\
(-5.61 \div 1.25) \\
(6.87)\end{array}$ & $\begin{array}{c}-0.42 \\
(-1.79 \div 0.73) \\
(2.52)\end{array}$ \\
\hline Classic/60 & $\begin{array}{c}-0.11 \\
(-1.00 \div 0.78) \\
(1.79)\end{array}$ & $\begin{array}{c}-0.05 \\
(-0.85 \div 0.73) \\
(1.59)\end{array}$ & $\begin{array}{c}-0.61 \\
(-1.34 \div 0.08) \\
(1.42)\end{array}$ & $\begin{array}{c}-1.38 \\
(-4.51 \div 1.04) \\
(5.54)\end{array}$ & $\begin{array}{c}-0.29 \\
(-1.36 \div 0.72) \\
(2.09)\end{array}$ \\
\hline II pass/48 & $\begin{array}{c}0.23 \\
(-0.41 \div 0.89) \\
(1.30)\end{array}$ & $\begin{array}{c}0.22 \\
(-0.13 \div 0.55) \\
(0.68)\end{array}$ & $\begin{array}{c}-0.26 \\
(-1.17 \div 0.59) \\
1.77)\end{array}$ & $\begin{array}{c}-0.96 \\
(-4.60 \div 2.05) \\
(6.65)\end{array}$ & $\begin{array}{c}-0.15 \\
(-1.14 \div 0.98) \\
(2.12)\end{array}$ \\
\hline II pass/60 & $\begin{array}{c}0.24 \\
(-0.39 \div 0.87) \\
(1.27)\end{array}$ & $\begin{array}{c}0.23 \\
(-0.11 \div 0.56) \\
(0.68)\end{array}$ & $\begin{array}{c}-0.30 \\
(-0.93 \div 0.41) \\
(1.34)\end{array}$ & $\begin{array}{c}-0.75 \\
(-3.38 \div 1.69) \\
(5.07)\end{array}$ & $\begin{array}{c}-0.06 \\
(-0.95 \div 1.02) \\
(1.97)\end{array}$ \\
\hline
\end{tabular}

Notes: The risk premium is estimated using the $N U M$ and $D E N$ portfolios. Other designations see Table 1.

Source: own research.

Table 3 shows the bootstrapped medians and confidence intervals of the cost of capital for investment in chosen stock indexes estimated by the classic CAPM. Panel A shows the values of the cost of capital if the risk premium is estimated using the $B / M$ and Size portfolios. Panel B shows the values of the cost of capital if the risk premium is estimated using the NUM and DEN portfolios.

If the cost of capital is estimated using the II pass procedure, then the median and confidence interval width of most indexes, estimated by the CAPM (built on the $B / M$ and Size portfolios) and the FF model take similar values. If the cost of capital is estimated using the classic procedure, then the median and confidence interval width of the DJIA, WIG20, WIGDIV, 
WIGCHEMIA indexes, estimated by the CAPM (built on the $B / M$ and Size portfolios) and the FF model take similar values.

Table 3. Percentage values of cost of capital (Ccap) for investment in chosen stock indexes estimated by the CAPM

\begin{tabular}{|c|c|c|c|c|c|c|}
\hline \multirow{3}{*}{$\begin{array}{c}\text { Est. } \\
\text { method/ } \\
\widehat{\beta_{i M}^{T}} \\
\text { periods } T, \\
\text { months }\end{array}$} & \multicolumn{6}{|c|}{$\begin{array}{c}\text { Cost of capital, } \% \text { monthly } \\
(95 \% \text { confidence interval) } \\
\text { (width of } 95 \% \text { confidence interval) }\end{array}$} \\
\hline & \multicolumn{3}{|c|}{ Classic procedure } & \multicolumn{3}{|c|}{$\begin{array}{c}\text { II pass procedure } \\
C \operatorname{Cap}_{i}=\widehat{\gamma_{0}}+\widehat{\gamma_{M}} \widehat{\beta_{i M}^{T}}\end{array}$} \\
\hline & DJIA & WIG20 & WIGDIV & mWIG80 & WIGBANK & WIGCHEMIA \\
\hline \multicolumn{7}{|c|}{ Panel A: Risk premium estimated using $B / M$ and Size portfolios } \\
\hline Classic/48 & $\begin{array}{c}0.78 \\
(0.27 \div 1.29) \\
(1.03)\end{array}$ & $\begin{array}{c}-0.32 \\
(-1.26 \div 0.57) \\
(1.83)\end{array}$ & $\begin{array}{c}-0.19 \\
(-1.02 \div 0.59) \\
1.60\end{array}$ & $\begin{array}{c}0.17 \\
(-0.39 \div 0.60) \\
(1.00)\end{array}$ & $\begin{array}{c}0.08 \\
(-1.98 \div 1.23) \\
(3.21)\end{array}$ & $\begin{array}{c}0.07 \\
(-0.85 \div 0.61) \\
(1.45)\end{array}$ \\
\hline Classic/60 & $\begin{array}{c}0.77 \\
(0.26 \div 1.28) \\
(1.02)\end{array}$ & $\begin{array}{c}-0.31 \\
(-1.21 \div 0.61) \\
(1.82)\end{array}$ & $\begin{array}{c}-0.18 \\
(-1.00 \div 0.61) \\
(1.61)\end{array}$ & $\begin{array}{c}0.10 \\
(-0.51 \div 0.62) \\
(1.13)\end{array}$ & $\begin{array}{c}0.08 \\
(-1.55 \div 0.99) \\
(2.54)\end{array}$ & $\begin{array}{c}0.09 \\
(-0.73 \div 0.62) \\
1.35\end{array}$ \\
\hline II pass $/ 48$ & $\begin{array}{c}0.97 \\
(0.89 \div 1.05) \\
(0.16)\end{array}$ & $\begin{array}{c}0.20 \\
(-0.42 \div 0.90) \\
(1.31)\end{array}$ & $\begin{array}{c}-0.04 \\
(-0.35 \div 0.41) \\
(0.76)\end{array}$ & $\begin{array}{c}-0.60 \\
(-1.63 \div 0.00) \\
(1.64)\end{array}$ & $\begin{array}{c}-0.29 \\
(-3.54 \div 2.76) \\
(6.29)\end{array}$ & $\begin{array}{c}-0.33 \\
(-1.58 \div 0.44) \\
(2.02)\end{array}$ \\
\hline II pass/60 & $\begin{array}{c}0.97 \\
(0.89 \div 1.05) \\
(0.16)\end{array}$ & $\begin{array}{c}0.18 \\
(-0.42 \div 0.84) \\
1.06\end{array}$ & $\begin{array}{c}-0.04 \\
(-0.36 \div 0.38) \\
(0.74)\end{array}$ & $\begin{array}{c}-0.49 \\
(-1.39 \div 0.02) \\
(1.37)\end{array}$ & $\begin{array}{c}-0.29 \\
(-3.06 \div 2.09) \\
(5.15)\end{array}$ & $\begin{array}{c}-0.37 \\
(-1.49 \div 0.27) \\
(1.75)\end{array}$ \\
\hline \multicolumn{7}{|c|}{ Panel B: Risk premium estimated using $N U M$ and $D E N$ portfolios } \\
\hline Classic/48 & - & $\begin{array}{c}-0.32 \\
(-1.26 \div 0.57) \\
(1.83)\end{array}$ & $\begin{array}{c}-0.19 \\
(-1.02 \div 0.59) \\
1.60\end{array}$ & $\begin{array}{c}0.17 \\
(-0.39 \div 0.60) \\
(1.00)\end{array}$ & $\begin{array}{c}0.08 \\
(-1.98 \div 1.23) \\
(3.21)\end{array}$ & $\begin{array}{c}0.07 \\
(-0.85 \div 0.61) \\
(1.45)\end{array}$ \\
\hline Classic/60 & - & $\begin{array}{c}-0.31 \\
(-1.21 \div 0.61) \\
(1.82)\end{array}$ & $\begin{array}{c}-0.18 \\
(-1.00 \div 0.61) \\
(1.61)\end{array}$ & $\begin{array}{c}0.10 \\
(-0.51 \div 0.62) \\
(1.13)\end{array}$ & $\begin{array}{c}0.08 \\
(-1.55 \div 0.99) \\
(2.54)\end{array}$ & $\begin{array}{c}0.09 \\
(-0.73 \div 0.62) \\
(1.35)\end{array}$ \\
\hline II pass $/ 48$ & - & $\begin{array}{c}0.00 \\
(-0.71 \div 0.74) \\
(1.45)\end{array}$ & $\begin{array}{c}-0.08 \\
(-0.42 \div 0.31) \\
(0.73)\end{array}$ & $\begin{array}{c}-0.22 \\
(-1.33 \div 0.72) \\
(2.05)\end{array}$ & $\begin{array}{c}-0.12 \\
(-2.54 \div 2.40) \\
(4.94)\end{array}$ & $\begin{array}{c}-0.15 \\
(-1.18 \div 0.70) \\
(1.88)\end{array}$ \\
\hline II pass $/ 60$ & - & $\begin{array}{c}-0.01 \\
(-0.67 \div 0.71) \\
(1.38)\end{array}$ & $\begin{array}{c}-0.07 \\
(-0.40 \div 0.30) \\
(0.70\end{array}$ & $\begin{array}{c}-0.20 \\
(-1.08 \div 0.53) \\
(1.60)\end{array}$ & $\begin{array}{c}-0.13 \\
(-2.14 \div 1.86) \\
(3.99)\end{array}$ & $\begin{array}{c}-0.16 \\
(-1.18 \div 0.60) \\
(1.78)\end{array}$ \\
\hline
\end{tabular}

Notes: other designations see Table 1.

Source: own research.

If the cost of capital is estimated using the II pass procedure, then the median of all indexes assumes negative values, except for the DJIA and WIG20 indexes for the portfolios built on $B / M$ and Size. If the cost of capital is estimated using the classic procedure, then the median of the mWIG80, WIGBANK and WIGCHEMIA indexes, estimated by the CAPM assumes positive values. 
The cost of capital median of index DJIA estimated by the CAPM and by the FF model, for two periods of beta estimation is positive. It is also noteworthy that the $2.5 \%$ confidence interval quantile assumes positive values in each case studied. Therefore, it can be unequivocally stated that, in contrast to the indexes of the Polish market, the cost of capital of the DJIA index is positive. Average values of the cost of capital median estimated according to the classic procedure are equal to approximately $0.81 \%$ per month - for the FF model and $0.77 \%$ per month - for the CAPM. Average values of the cost of capital median estimated according to the II pass procedure are equal to approximately $0.86 \%$ per month - for the FF model and $0.97 \%$ per month - for the CAPM. The average confidence interval width for the II pass method is about 5.6 times smaller, which means that the cost of capital is estimated with several times higher accuracy.

Table 4 shows the bootstrapped medians and confidence intervals of the cost of capital for investment in WIG30, estimated by the FF and MFF models and different penny thresholds.

Figure 1 shows the distributions of the bootstrapped medians of the cost of capital for investment in the WIG30, estimated by the FF and MFF models and different penny thresholds.

The elimination of penny stocks does not cause significant changes in the cost of capital estimated using the FF and MFF models, and the classic procedure. The estimated cost of capital median according to the classic procedure is negative and amounts to about $-0.2 \%$.

If the II pass procedure is used, the elimination of penny stocks with prices from 0.5 to 5 PLN results in an increase in the cost of capital from about 0.2 to $0.35 \%$ per month for the FF model, and from 0.2 to $0.6 \%$ per month for the MFF model.

Table 4. Percentage values of the cost of capital (Ccap) estimated by the classic (FF) and modified (MFF) Fama-French model, and different penny thresholds for investment in the WIG30

\begin{tabular}{|c|c|c|c|c|c|c|c|}
\hline \multirow{2}{*}{$\begin{array}{c}\text { Estim. } \\
\text { method/ } \\
\widehat{\beta_{i M}^{T}} \\
\text { periods } T, \\
\text { months }\end{array}$} & \multicolumn{7}{|c|}{$\begin{array}{c}\text { WIG30 Cost of capital, } \% \text { monthly } \\
(95 \% \text { confidence interval) } \\
\text { (width of } 95 \% \text { confidence interval) } \\
\text { Penny threshold = }\end{array}$} \\
\hline & $=0.0$ & $=0.5$ & $=1.0$ & $=2.0$ & $=3.0$ & $=4.0$ & $=5.0$ \\
\hline 1 & 2 & 3 & 4 & 5 & 6 & 7 & 8 \\
\hline \multicolumn{8}{|c|}{ Panel A: ICAPM, FF model, $B / M$ and Size portfolios } \\
\hline \multicolumn{8}{|c|}{$\begin{array}{l}\operatorname{Ccap}_{i}=\widehat{E(R F)}+\widehat{E(R M-R F)} \widehat{\beta_{i M}^{T}}+ \\
+\widehat{E(H M L) \widehat{\beta_{i, H M L}}}+\widehat{E(S M B) \widehat{\beta_{i, S M B}}}\end{array}$} \\
\hline Classic/48 & $\begin{array}{c}-0.25 \\
(-1.16 \div 0.61) \\
(1.78)\end{array}$ & $\begin{array}{c}-0.25 \\
(-1.17 \div 0.61) \\
(1.78)\end{array}$ & $\begin{array}{c}-0.25 \\
(-1.18 \div 0.60) \\
(1.79)\end{array}$ & $\begin{array}{c}-0.29 \\
(-1.22 \div 0.56) \\
(1.78)\end{array}$ & $\begin{array}{c}-0.28 \\
(-1.20 \div 0.58) \\
(1.77)\end{array}$ & $\begin{array}{c}-0.29 \\
(-1.20 \div 0.57) \\
(1.77)\end{array}$ & $\begin{array}{c}-0.28 \\
(-1.21 \div 0.58) \\
(1.78)\end{array}$ \\
\hline
\end{tabular}




\begin{tabular}{|c|c|c|c|c|c|c|c|}
\hline 1 & 2 & 3 & 4 & 5 & 6 & 7 & 8 \\
\hline Classic/60 & $\begin{array}{c}-0.23 \\
(-1.09 \div 0.66) \\
(1.75)\end{array}$ & $\begin{array}{c}-0.21 \\
(-1.07 \div 0.66) \\
(1.71)\end{array}$ & $\begin{array}{c}-0.20 \\
(-1.06 \div 0.69) \\
(1.74)\end{array}$ & $\begin{array}{c}-0.21 \\
(-1.07 \div 0.66) \\
(1.74)\end{array}$ & $\begin{array}{c}-0.22 \\
(-1.09 \div 0.65) \\
(1.73)\end{array}$ & $\begin{array}{c}-0.23 \\
(-1.08 \div 0.64) \\
(1.72)\end{array}$ & $\begin{array}{c}-0.25 \\
(-1.11 \div 0.62) \\
(1.73)\end{array}$ \\
\hline II pass $/ 48$ & $\begin{array}{c}0.23 \\
(-0.22 \div 0.75) \\
(0.97)\end{array}$ & $\begin{array}{c}0.21 \\
(-0.23 \div 0.74) \\
(1.35)\end{array}$ & $\begin{array}{c}0.26 \\
(-0.17 \div 0.79) \\
(0.96)\end{array}$ & $\begin{array}{c}0.26 \\
(-0.17 \div 0.78) \\
(0.95)\end{array}$ & $\begin{array}{c}0.33 \\
(-0.08 \div 0.82) \\
(0.91)\end{array}$ & $\begin{array}{c}0.37 \\
(-0.02 \div 0.84) \\
(0.85)\end{array}$ & $\begin{array}{c}0.39 \\
(-0.04 \div 0.88) \\
(0.92)\end{array}$ \\
\hline II pass $/ 60$ & $\begin{array}{c}0.16 \\
(-0.23 \div 0.67) \\
(0.90)\end{array}$ & $\begin{array}{c}0.16 \\
(-0.25 \div 0.68) \\
(1.10)\end{array}$ & $\begin{array}{c}0.23 \\
(-0.18 \div 0.78) \\
(0.96)\end{array}$ & $\begin{array}{c}0.27 \\
(-0.13 \div 0.82) \\
(0.95)\end{array}$ & $\begin{array}{c}0.31 \\
(-0.07 \div 0.82) \\
(0.89\end{array}$ & $\begin{array}{c}0.34 \\
(-0.04 \div 0.83) \\
(0.86)\end{array}$ & $\begin{array}{c}0.33 \\
(-0.07 \div 0.85) \\
(0.91)\end{array}$ \\
\hline \multicolumn{8}{|c|}{ Panel B: ICAPM, MFF model, NUM and DEN portfolios } \\
\hline \multicolumn{4}{|c|}{ Classic procedure } & \multicolumn{4}{|c|}{$\operatorname{Ccap}_{i}=\widehat{\gamma_{0}}+\widehat{\gamma_{M}} \widehat{\beta_{i M}}+\widehat{\gamma_{H M L N}} \widehat{\beta_{i, H M L N}}+\widehat{\gamma_{L M H D}} \widehat{\beta_{i, L M H D}}$} \\
\hline Classic/48 & $\begin{array}{c}-0.15 \\
(-1.07 \div 0.71) \\
(1.77)\end{array}$ & $\begin{array}{c}-0.17 \\
(-1.09 \div 0.69) \\
(1.78)\end{array}$ & $\begin{array}{c}-0.19 \\
(-1.11 \div 0.66) \\
(1.77)\end{array}$ & $\begin{array}{c}-0.23 \\
(-1.15 \div 0.65) \\
(1.80)\end{array}$ & $\begin{array}{c}-0.24 \\
(-1.17 \div 0.61) \\
(1.78)\end{array}$ & $\begin{array}{c}-0.22 \\
(-1.12 \div 0.65) \\
(1.78)\end{array}$ & $\begin{array}{c}-0.18 \\
(-1.11 \div 0.68) \\
(1.78)\end{array}$ \\
\hline Classic/60 & $\begin{array}{c}-0.09 \\
(-0.93 \div 0.78) \\
(1.70)\end{array}$ & $\begin{array}{c}-0.12 \\
(-0.97 \div 0.74) \\
(1.71)\end{array}$ & $\begin{array}{c}-0.18 \\
(-1.04 \div 0.69) \\
(1.73) \\
\end{array}$ & $\begin{array}{c}-0.25 \\
(-1.10 \div 0.62) \\
(1.74)\end{array}$ & $\begin{array}{c}-0.25 \\
(-1.11 \div 0.62) \\
(1.74)\end{array}$ & $\begin{array}{c}-0.19 \\
(-1.05 \div 0.68) \\
(1.73) \\
\end{array}$ & $\begin{array}{c}-0.17 \\
(-1.02 \div 0.72) \\
(1.73)\end{array}$ \\
\hline II pass $/ 48$ & $\begin{array}{c}0.20 \\
(-0.37 \div 0.81) \\
(1.18)\end{array}$ & $\begin{array}{c}0.10 \\
(-0.55 \div 0.80) \\
(1.35)\end{array}$ & $\begin{array}{c}0.16 \\
(-0.40 \div 0.76) \\
(1.16)\end{array}$ & $\begin{array}{c}0.05 \\
(-0.60 \div 0.65) \\
(1.25)\end{array}$ & $\begin{array}{c}0.31 \\
(-0.29 \div 0.92) \\
1.74\end{array}$ & $\begin{array}{c}0.55 \\
(0.03 \div 1.05) \\
(1.02)\end{array}$ & $\begin{array}{c}0.63 \\
(0.04 \div 1.26) \\
(1.21) \\
\end{array}$ \\
\hline II pass $/ 60$ & $\begin{array}{c}0.23 \\
(-0.25 \div 0.70) \\
(0.95)\end{array}$ & $\begin{array}{c}0.15 \\
(-0.41 \div 0.70) \\
(1.10)\end{array}$ & $\begin{array}{c}0.14 \\
(-0.35 \div 0.67) \\
(1.02)\end{array}$ & $\begin{array}{c}0.05 \\
(-0.52 \div 0.55) \\
(1.07)\end{array}$ & $\begin{array}{c}0.25 \\
(-0.25 \div 0.82) \\
(1.08)\end{array}$ & $\begin{array}{c}0.48 \\
(0.05 \div 0.97) \\
(0.92)\end{array}$ & $\begin{array}{c}0.56 \\
(0.06 \div 1.11) \\
(1.06)\end{array}$ \\
\hline
\end{tabular}

Notes: other designations see Table 1.

Source: own research.
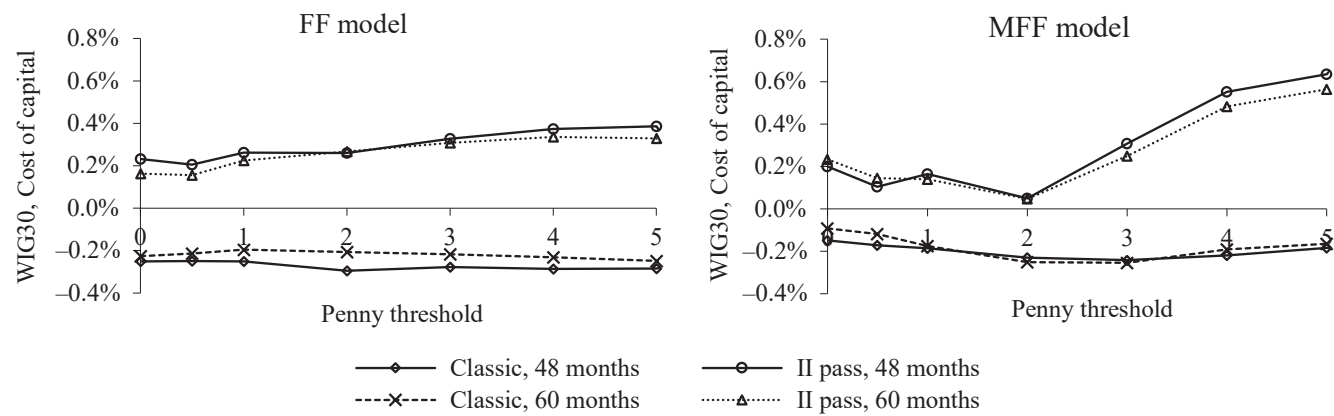

Notes: This figure presents the bootstrapped median of the cost of capital for investment in the portfolio consisting of companies included in index WIG30. The systematic risk components $(\beta)$ are estimated using 48 and the last 60 months. The risk premium components $(\gamma)$ are estimated by the classic procedure and II pass econometrical model, with penny stocks elimination, using the whole historical period of 276 months, 1995-2019.

Figure 1. Cost of capital estimated for different penny thresholds for investment in index WIG30 Source: own research. 
Table 5 shows the bootstrapped medians and confidence intervals of the cost of capital for investment in WIG30, estimated by the CAPM and different penny thresholds.

Table 5. Cost of capital estimated by the CAPM and different penny thresholds for investment in WIG30

\begin{tabular}{|c|c|c|c|c|c|c|c|c|}
\hline \multirow{4}{*}{$\begin{array}{l}\text { Estim. } \\
\text { method }\end{array}$} & \multirow{4}{*}{$\begin{array}{c}\widehat{\beta_{i M}^{T}} \\
\text { periods } T \\
\text { months }\end{array}$} & \multicolumn{7}{|c|}{$\begin{array}{l}\text { WIG30 Cost of capital, } \% \text { monthly } \\
\quad(95 \% \text { confidence interval) } \\
\text { (width of } 95 \% \text { confidence interval) }\end{array}$} \\
\hline & & \multicolumn{4}{|c|}{$\operatorname{Ccap}_{i}=\widehat{E(R F)}+\widehat{E(R M-R F)} \widehat{\beta_{i M}^{T}}$} & \multicolumn{3}{|c|}{ II pass procedure } \\
\hline & & \multicolumn{7}{|c|}{ Penny threshold $=$} \\
\hline & & $=0.0$ & $=0.5$ & $=1.0$ & $=2.0$ & $=3.0$ & $=4.0$ & $=5.0$ \\
\hline \multicolumn{9}{|c|}{ Panel A: CAPM, $B / M$ and $C A P$ portfolios } \\
\hline \multirow{2}{*}{ Classic } & 48 & \multicolumn{7}{|c|}{$\begin{array}{c}-0.29 \\
(-1.20 \div 0.58) \\
(1.77)\end{array}$} \\
\hline & 60 & \multicolumn{7}{|c|}{$\begin{array}{c}-0.26 \\
(-1.12 \div 0.61) \\
(1.73)\end{array}$} \\
\hline \multirow{2}{*}{ II pass } & 48 & $\begin{array}{c}0.15 \\
(-0.40 \div 0.77) \\
(1.17)\end{array}$ & $\begin{array}{c}0.10 \\
(-0.47 \div 0.73) \\
(1.20)\end{array}$ & $\begin{array}{c}0.14 \\
(-0.41 \div 0.74) \\
(1.15)\end{array}$ & $\begin{array}{c}0.14 \\
(-0.37 \div 0.68) \\
(1.05)\end{array}$ & $\begin{array}{c}0.10 \\
(-0.38 \div 0.63) \\
(1.01)\end{array}$ & $\begin{array}{c}0.20 \\
(-0.26 \div 0.67) \\
(0.94)\end{array}$ & $\begin{array}{c}0.19 \\
(-0.29 \div 0.68) \\
(0.97\end{array}$ \\
\hline & 60 & $\begin{array}{c}0.10 \\
(-0.39 \div 0.66) \\
(1.05)\end{array}$ & $\begin{array}{c}0.05 \\
(-0.43 \div 0.62) \\
(1.05)\end{array}$ & $\begin{array}{c}0.08 \\
(-0.39 \div 0.62) \\
(1.01)\end{array}$ & $\begin{array}{c}0.09 \\
(-0.34 \div 0.61) \\
(0.95)\end{array}$ & $\begin{array}{c}0.06 \\
(-0.35 \div 0.54) \\
(0.89)\end{array}$ & $\begin{array}{c}0.15 \\
(-0.24 \div 0.59) \\
(0.83)\end{array}$ & $\begin{array}{c}0.14 \\
(-0.27 \div 0.63) \\
(0.89)\end{array}$ \\
\hline \multicolumn{9}{|c|}{ Panel B: CAPM, $N U M$ and $D E N$ portfolios } \\
\hline \multirow{2}{*}{ Classic } & 48 & \multicolumn{7}{|c|}{$\begin{array}{c}-0.29 \\
(-1.20 \div 0.58) \\
(1.77)\end{array}$} \\
\hline & 60 & \multicolumn{7}{|c|}{$\begin{array}{c}-0.26 \\
(-1.12 \div 0.61) \\
(1.73)\end{array}$} \\
\hline \multirow{2}{*}{ II pass } & 48 & $\begin{array}{c}-0.01 \\
(-0.64 \div 0.63) \\
(1.26)\end{array}$ & $\begin{array}{c}-0.26 \\
(-0.94 \div 0.46) \\
(1.40)\end{array}$ & $\begin{array}{c}-0.20 \\
(-0.80 \div 0.37) \\
(1.16)\end{array}$ & $\begin{array}{c}-0.13 \\
(-0.86 \div 0.56) \\
(1.42)\end{array}$ & $\begin{array}{c}0.02 \\
(-0.68 \div 0.71) \\
(1.39)\end{array}$ & $\begin{array}{c}0.26 \\
(-0.34 \div 0.89) \\
(1.23)\end{array}$ & $\begin{array}{c}0.15 \\
(-0.57 \div 0.85) \\
(1.42)\end{array}$ \\
\hline & 60 & $\begin{array}{c}-0.03 \\
(-0.56 \div 0.55) \\
(1.11)\end{array}$ & $\begin{array}{c}-0.24 \\
(-0.84 \div 0.37) \\
(1.20)\end{array}$ & $\begin{array}{c}-0.19 \\
(-0.72 \div 0.33) \\
(1.05)\end{array}$ & $\begin{array}{c}-0.12 \\
(-0.76 \div 0.48) \\
(1.24)\end{array}$ & $\begin{array}{c}0.00 \\
(-0.60 \div 0.63) \\
(1.22)\end{array}$ & $\begin{array}{c}0.21 \\
(-0.29 \div 0.81) \\
(1.10)\end{array}$ & $\begin{array}{c}0.10 \\
(-0.51 \div 0.76) \\
(1.26)\end{array}$ \\
\hline
\end{tabular}

Notes: If the II pass procedure is used the risk premium $\widehat{\gamma_{M}}$ is estimated with penny stocks elimination. The elimination of penny stocks changes the risk and risk premium estimated by the II pass procedure. The elimination of penny stocks does not change the risk and risk premium estimated by the classic procedure. Other designations see Table 1.

Source: own research.

Figure 2 shows the distributions of the bootstrapped medians of the cost of capital for investment in WIG30, estimated by the CAPM and different penny thresholds. 


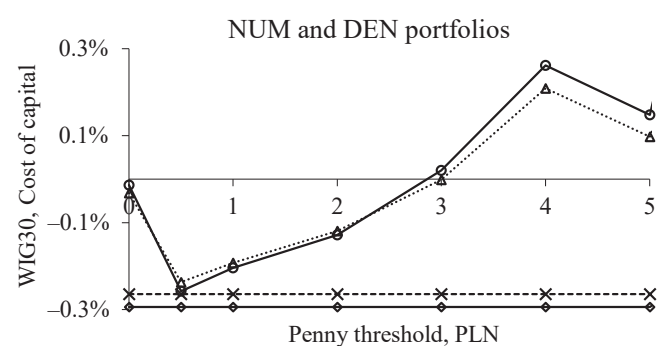

$\longrightarrow$ Classic, 48 months

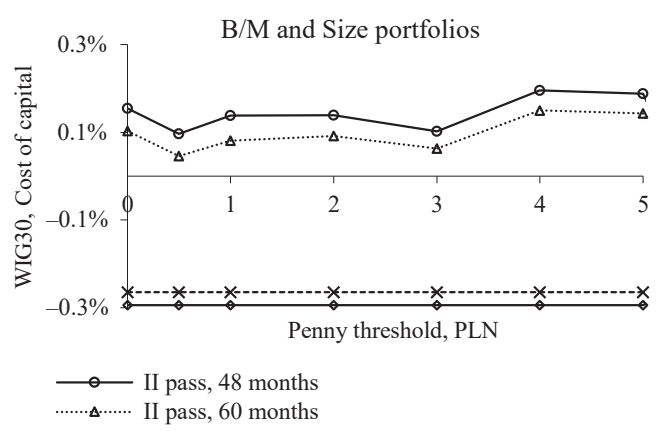

Notes: if the II pass procedure is used the risk premium $\widehat{\gamma_{M}}$ is estimated with penny stocks elimination. The elimination of penny stocks changes the risk and risk premium estimated by the II pass procedure. The elimination of penny stocks does not change the risk and risk premium estimated by the classic procedure. Other designations see Figure 1 .

Figure 2. Cost of capital estimated by the CAPM for different penny thresholds for investment in index WIG30

Source: own research.

If the CAPM is applied and the classic procedure is used, the cost of capital remains unchanged for various penny stock thresholds. ${ }^{6}$ If the II pass procedure is used, the elimination of penny stocks with prices from 0.5 to $5 \mathrm{PLN}$, similarly to the estimation with the FF and MFF models, results in an increase in the cost of capital from about -0.2 to $0.2 \%$ per month.

Table 6 shows $p$-values of a normality statistic of the bootstrapped cost of capital using 48 and 60 last month periods (from the whole period of 276 months) for beta estimation. Table 6 also shows the results of the Wilcoxon rank sum test examining the equality of bootstrapped medians of the cost of capital using betas estimated from 48 and 60 periods (hereafter denoted as $\beta^{48}$ and $\beta^{60}$ ).

The length of the beta estimation period has a considerable influence on the bootstrapped median of the cost of capital for all of the indexes tested. Due to the different confidence intervals, the bootstrapped medians of the cost of capital estimated using the $\beta^{48}$ and $\beta^{60}$ are significantly different at the level of about $0.00 \%$ (for almost all of the tested indexes and the both Procedures, and the CAPM and FF models, see Table 6). ${ }^{7}$

\footnotetext{
6 This is due to the assumption that the elimination of penny stocks does not change the composition of the market portfolio. The elimination of penny stocks, on the other hand, changes all risk and risk premium components estimated by the II pass procedure. The elimination of penny stocks also changes the risk and risk premium components for $H M L /$ $H M L N$ and $S M B / L M H D$, and does not change the $R M$ component estimated by the classic procedure.

7 The cost of capital medians for the WIGBANK index are equal for the CAPM (using the II pass procedure and portfolios formed on $B / M$ and Size) and the last 48 and 60 periods of estimation.
} 
The bootstrapped medians of the cost of capital estimated by the classic and II pass procedures are significantly different (at the level of about $0.00 \%$ ) for the CAPM, FF and MFF pricing applications. ${ }^{8}$

Table 6. Statistics of the bootstrapped distribution tests of the cost of capital (Ccap) using betas estimated from 48 and 60 months

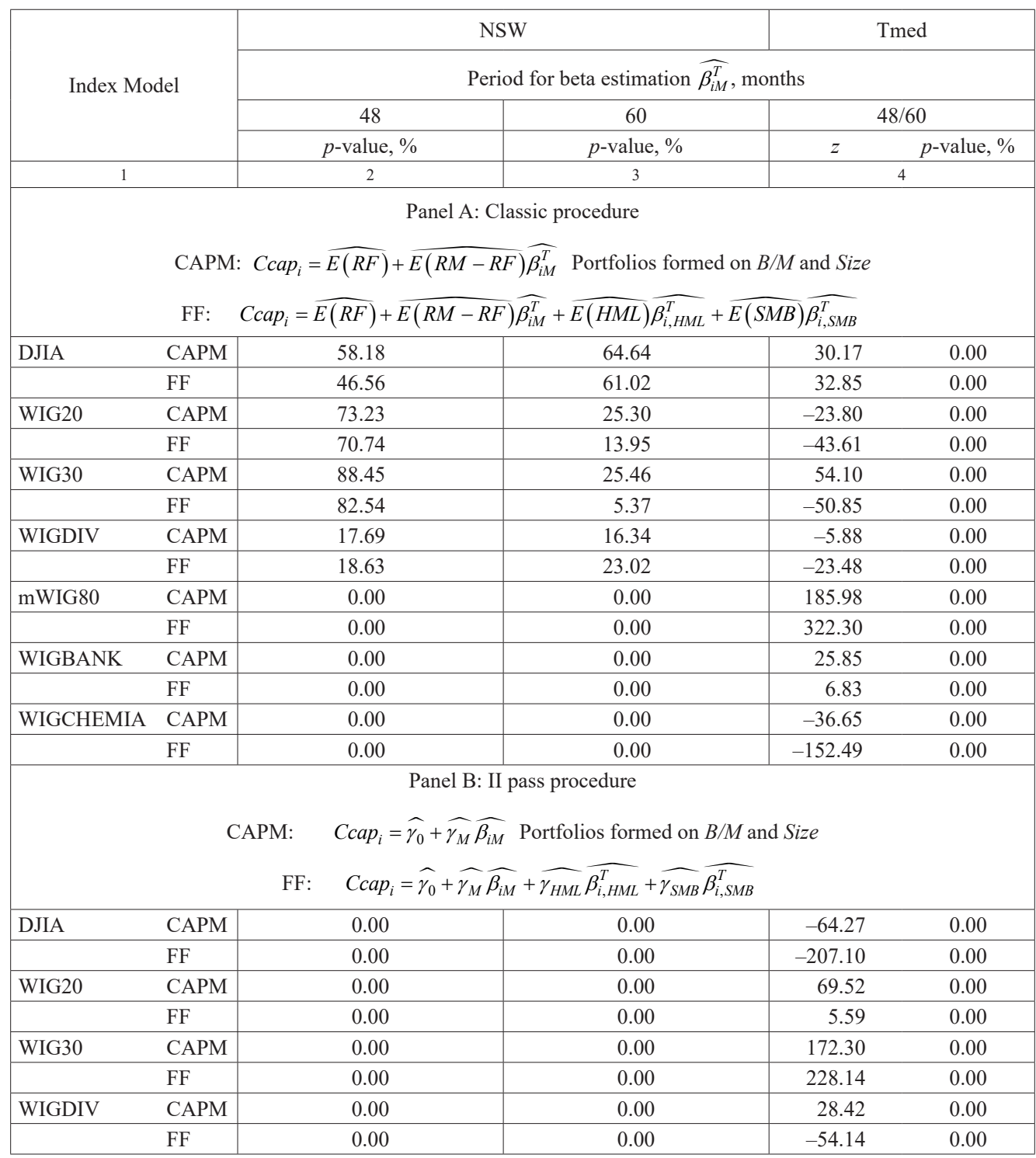

\footnotetext{
8 The results of the Wilcoxon rank sum test for medians differences (estimated by both procedures, and estimated from 48 and 60 periods) are available from the author on request.
} 


\begin{tabular}{|rl|c|c|rr|}
\hline \multicolumn{2}{|c|}{1} & 2 & 3 & \multicolumn{2}{c|}{4} \\
\hline mWIG80 & CAPM & 0.00 & 0.00 & -231.57 & 0.00 \\
\hline & FF & 0.00 & 0.00 & -31.98 & 0.00 \\
\hline WIGBANK & CAPM & 0.00 & 0.00 & 0.69 & 24.64 \\
\hline & FF & 0.00 & 0.00 & -2.06 & 3.98 \\
\hline WIGCHEMIA & CAPM & 0.00 & 0.00 & 16.41 & 0.00 \\
\hline & FF & 0.00 & 0.00 & 0.00 \\
\hline
\end{tabular}

Notes: This table presents the $p$-values of the chosen statistical tests of the bootstrapped distribution of the cost of capital for chosen indexes estimated by the CAPM, the classic Fama-French model (FF) and the modified Fama-French model (MFF). NSW - Shapiro-Wilk normality test, $\mathrm{H}_{0}$ : the distribution is normal; Tmed - Wilcoxon rank sum test, $z$-standardized test statistic, $\mathrm{H}_{0}$ : the medians are equal; the systematic risk components $(\beta)$ are estimates using 48 and 60 of the last months. The risk premium components $(\gamma)$ are estimates by the classic procedure and II pass econometrical model using the whole historical period of 276 months, 1995-2019.

Source: own research.

\section{Cost of capital for WSE indexes versus DJIA - discussion}

Available data allow the use of the FF model to estimate the cost of capital for the DJIA index.

The tested pricing applications (FF and MFF models), using market returns, do not generate fully multifactor-efficient portfolios neither on the Polish market nor on the American market (see Urbański, Zarzecki, 2021). This fact may result in an inaccurate estimation of the cost of capital. It can be assumed that the cited phenomenon is reflected by the wide confidence intervals of the estimated cost of capital found in this study (see Tables from 1 to 5). Wide confidence intervals of the cost of capital may result in negative median values or negative confidence limits. In other words, an inaccurate estimation of the cost of capital may be due to a pricing inconsistent in light of the ICAPM.

The basic assumption of CAPM/ICAPM is a rational pricing of capital by a representative investor. On the other hand, the irrational pricing of assets may be a factor generating price anomalies, and the cost of capital can be estimated with a large error, which results in a wide estimated confidence interval.

In the case of this research, the average confidence intervals of the cost of capital of Polish indices are several times wider than the confidence interval of the DJIA index. It may also be the result of negatively estimated medians of the cost of capital of the Polish indexes.

One could assume that the returns of some Polish firms may be partly due to factors that contradict the rational pricing of capital. It can be assumed that behavioural factors have a large impact on the generated returns. 
In the case of the DJIA index, the medians and the lower limits of the confidence interval (estimated with the classic CAPM and the FF model, using the Classic and II pass procedures) assume positive values. It can be assumed that the influence of behavioural factors on the generated returns is lower than in the case of the Polish market.

\section{Conclusions}

The performed research leads to the following conclusions:

1. The estimated cost of capital based on the examined CAPM and ICAPM applications is the expected return on investment in the stock portfolio representing the examined index.

2. Positive cost of capital values are found only for the DJIA.

3. Positive cost of capital medians are found for the following indices:

- DJIA estimated by the CAPM, FF model, and all the tested cases, about $0.85 \%$ per month,

- WIG20 estimated by the II pass of the CAPM, FF and MFF models, about $0.25 \%$ per month,

- WIGDIV estimated by the II pass of the MFF model, about $0.3 \%$ per month,

- WIGCHEMIA estimated by the classic procedure of the CAPM and the FF model, about $0.07 \%$ per month,

- mWIG80 estimated by the classic procedure of the CAPM, about $0.15 \%$ per month,

- WIGBANK estimated by the classic procedure of the CAPM, about $0.08 \%$ per month.

4. The cost of capital for most of the indexes tested is estimated similarly using the CAPM and the FF model. This is consistent with the conjecture made in the Introduction section.

5. The cost of capital of the WIG20 index is estimated similarly using the FF and MFF models. This is in line with the adopted conjecture. However, in the case of the WIGDIV, mWIG80, WIGBANK and WIGCHEMIA indexes, the differences between the value of the cost of capital estimated by the FF and MFF models are greater, which does not confirm the adopted conjecture.

6. The bootstrapped medians of the cost of capital assessed using 48 and 60 monthly periods of systematic risk estimation are significantly different for the all examined indexes. 
7. The bootstrapped medians of the cost of capital estimated on the basis of the classic and II pass procedures for the indexes examined show significant differences.

8. The width of the confidence interval for the cost of capital of the Polish stock indexes is several times larger than in the case of the DJIA index. This indicates a much smaller error in estimating the cost of capital for the DJIA index.

9. Much smaller estimation errors and positive values of the cost of capital investment in the DJIA index compared to the case of the Polish stock indexes may result from:

- a more rational policy for the implementation of investment projects by companies included in the DJIA index,

- the lower impact of the behavioural pricing of stock included in index DJIA,

- other unknown factors requiring further study.

\section{Appendix}

The pricing application MFF was originally proposed by Urbanski (2012) and revised according to the following procedure.

Fama and French's (1995) research states that future returns are dependent on the changes of the past long term ratios of earnings to the book value of the company. Therefore, the general state variable can be reflected by $F U N$, which is defined by equations $(1 \mathrm{~A}),(2 \mathrm{~A})$ and $(3 \mathrm{~A}) .{ }^{9}$

$$
F U N=\frac{N U M}{D E N}=\frac{\operatorname{nor}(R O E) \times \operatorname{nor}(A S B) \times \operatorname{nor}(A P O B) \times \operatorname{nor}(A P N B)}{\operatorname{nor}(M E) \times \operatorname{nor}(M B)}
$$

where

$$
\begin{gathered}
R O E=F_{1} ; A S B=F_{2}=\frac{\left\{\sum_{t=1}^{i}\left[S\left(Q_{t}\right)\right]\right\} / B V\left(Q_{t}\right)}{\sum_{t=1}^{i} \overline{S B V\left(n Q_{t}\right)}} \\
A P O B=F_{3}=\frac{\left\{\sum_{t=1}^{i}\left[P O\left(Q_{t}\right)\right]\right\} / B V\left(Q_{t}\right)}{\sum_{t=1}^{i} \overline{P O B V\left(n Q_{t}\right)}} \\
A P N B=F_{4}=\frac{\left\{\sum_{t=1}^{i}\left[P N\left(Q_{t}\right)\right]\right\} / B V\left(Q_{t}\right)}{\sum_{t=1}^{i} \overline{P N B V\left(n Q_{t}\right)}} ; M E=F_{5} ; M B=F_{6}
\end{gathered}
$$

$F_{j}(j=1, \ldots, 6)$ are transformed to the normalized areas $\left\langle a_{j} ; b_{j}\right\rangle$ according to Eq. (3A):

$$
\operatorname{nor}\left(F_{j}\right)=\left[a_{j}+\left(b_{j}-a_{j}\right) \times \frac{F_{j}-c_{j} \times F_{j}^{\min }}{d_{j} \times F_{j}^{\max }-c_{j} \times F_{j}^{\min }+e_{j}}\right.
$$

\footnotetext{
9 The FUN proposed by Urbanski (2012) is modified, originally proposed by Urbanski and Leskow (2020).
} 
$R O E$ is return on book value; $\sum_{t=1}^{i} S\left(Q_{t}\right), \sum_{t=1}^{i} P O\left(Q_{t}\right)$, and $\sum_{t=1}^{i} P N\left(Q_{t}\right)$ are respectively the net sales revenue $(S)$, operating profits $(P O)$ and net profits $(P N)$ that are accumulated from the beginning of the year to the end of $i$ quarter $\left(Q_{i}\right) ; \sum_{t=1}^{i} \overline{S B V\left(n Q_{t}\right)}, \sum_{t=1}^{i} \overline{P O B V\left(n Q_{t}\right)}$, and $\sum_{t=1}^{i} \overline{P N B V\left(n Q_{t}\right)}$ are respectively the average $S / B V, P O / B V$ and $P N / B V$ that are accumulated from the beginning of the year to the end of $Q_{i}$ over the last $n$ years; $B V$ is the book value; $M E$ is the market-to-earnings (for the last four quarters) ratio; $M B$ is the market-to-book value ratio; and $a_{j}, b_{j}, c_{j}, d_{j}$, and $e_{j}$ are the variation parameters.

In the case of the MFF model, the risk factors are defined as follows:

$$
F_{1 t}=R M_{t}-R F_{t}, F_{2 t}=H M L N_{t}, F_{3 t}=L M H D_{t}
$$

where $H M L N_{t}$ is the difference between the returns from the portfolio with the highest and lowest $N U M_{t}$ values in period $t ; L M H D_{t}$ is the difference between the returns from the portfolio with the lowest and highest $D E N_{t}$ values in period $t$; and $R M_{t}-R F_{t}$ is the market factor, which is defined as the excess return of the stock index over the risk-free rate.

Considering (4A), pricing model (1) can be rewritten as follows:

$$
E\left(r_{i}\right)=E(R F)+\beta_{i, M} E(R M-R F)+\beta_{i, H M L N} E(H M L N)+E(L M H D)
$$

\section{References}

Barnes, M.L., Lopez, J.A. (2006). Alternative measures of the Federal Reserve Banks cost of equity capital. Journal of Banking and Finance, 30, 1687-1711.

Berk, J., Green, R., Naik, V. (1999). Optimal investment, growth options, and security returns. Journal of Finance, 54, 1553-1607.

Bernardo, A., Chowdry, B., Goyal, A. (2007). Growth options, beta, and the cost of capital. Financial Management, 36, 5-17.

Bhandari, L.CH. (1988). Debt/Equity Ratio and Expected Common Stock Returns: Empirical Evidence. Journal of Finance, 43 (2), 507-528.

Efron, B., Tibshirani, RJ. (1993). An Introduction to the Bootstrap. Chapman and Hall CRC, New York. 
Fama, E.F. (1996). Multifactor Portfolio Efficiency and Multifactor As-set Pricing. Journal of Financial and Quantitative Analysis, 31 (4), 441-465.

Fama, E.F., French, K.R. (1992). The Cross-Section of Expected Stock Returns. Journal of Finance, 47 (2), 427-465.

Fama, E.F., French, K.R. (1993). Common Risk Factors in the Returns on Stock and Bonds. Journal of Financial Economics, 33 (1), 3-56.

Fama, E.F., French, K.R. (1995). Size and Book-to-Market Factors in Earnings and Returns. Journal of Finance, 50 (1), 131-155.

Ferson, W., Locke, D.H. (1998), Estimating the cost of capital through time: An Analysis of the Sources of Error. Management Science, 44 (4), 485-500.

Hamada, R.S. (1972). The Effect of the Firm's Capital Structure on the Systematic Risk of Common Stocks. Journal of Finance, 27 (2), 435-452.

Jagannathan, R., Wang, Z. (1996). The Conditional CAPM and the Cross-Section of Expected Returns. Journal of Finance, 51 (1), 3-53.

Jegadeesh, N., Titman, S. (1993). Returns to Buying Winners and Selling Losers: Implications for Stock Market Efficiency. Journal of Finance, 48 (1), 65-91.

King, R.M. (2009). The cost of equity for global banks: a CAPM perspective from 1990 to 2009. BIS Quarterly Review, 8, 59-73.

Kozarević, E., Džafić, J. (2014). Capital Asset Pricing Model and the Cost of Equity Share Capital on the Sarajevo Stock Exchange. Journal of Empirical Economics, 2 (2), 88-96.

Lakonishok, J., Shleifer, A., Vishny R. (1994). W. Contrarian investment, extrapolation, and risk, Journal of Finance, 49, 1541-1578.

Merton, R.C. (1973). An Intertemporal Capital Asset Pricing Model. Econometrica, 41 (5), $867-888$.

Pratt, S.P. (2002). Cost of Capital. Estimation and Applications. New Jersey: John Wiley \& Sons, Inc. Hoboken.

Rosenberg, B., Reid, K., Lanstein, R. (1985). Persuasive Evidence of Market Inefficiency. Journal of Portfolio Management, 11 (3), 9-16.

Shanken, J. (1992). On the Estimation of Beta-Pricing Models. The Review of Financial, 5 (1), 1-33.

Urbanski, S. (2012). Multifactor Explanations of Returns on the Warsaw Stock Exchange in Light of the ICAPM. Economic Systems, 36, 552-570.

Urbański, S. (2019). The cost of equity capital in stock portfolios listed on the Warsaw Stock Exchange using the classic CAPM. Financial Internet Quarterly e-Finanse, 15 (2), 48-62.

Urbański, S., Leśkow, J. (2020). Using the ICAPM to estimate the cost of capital of stock portfolios: empirical evidence on the Warsaw Stock Exchange. Statistic in Transition new series, 21 (1), 1-10. 
Urbański, S., Zarzecki, D., Leśkow, J. (2020). Using the ICAPM to Estimate the Cost of Capital: Developed Market and Polish Market Stock Portfolios. 35th IBIMA Conference, Seville, pp. 12858-12870.

Urbański, S., Zarzecki, D. (2021). The Fama-French model for Estimating the Cost of Equity Capital: Impact of Real Options of Investment Projects. Economic Systems, accepted for publication.

Zhi, D., Guo, R.J., Jagannathan, R. (2012). CAPM for estimating the cost of equity capital: Interpreting the empirical evidence. Journal of Financial Economics, 103 (1), 204-220. 